\title{
PPAR $\gamma$-Induced Stimulation of Amiloride- Sensitive Sodium Current in Renal Collecting Duct Principal Cells is Serum and Insulin Dependent
}

\author{
Ahmed Chraïbi Stéphane Renauld
}

Department of Physiology and Biophysics, Faculty of Medicine and Health Sciences Universite de Sherbrooke, Sherbrooke, Québec, Canada

\author{
Key Words \\ $\mathrm{ENaC} \cdot$ Rosiglitazone $\bullet \mathrm{PPAR} \gamma \cdot \mathrm{Nedd} 4 \cdot \mathrm{SGK} 1 \cdot \mathrm{mpkCCD}_{\mathrm{c} 14}$
}

\begin{abstract}
Background/Aims: Thiazolidinediones (TZDs), such as rosiglitazone or pioglitazone, are peroxisome proliferator-activated receptor gamma (PPAR $\gamma$ ) agonists currently used in the treatment of type 2 diabetes. However, their clinical applicability is limited by common and severe side effects including strong water retention, edema and cardiac stroke. The precise mechanisms leading to these disorders are not clearly understood and remain controversial. While the nature of the disorders due to TZDs points to an increase in ENaC-mediated sodium reabsorption in the aldosterone-sensitive distal nephron, some studies suggested that this channel was not targeted by PPARy agonists. Methods: Mouse cortical collecting duct cells were incubated in different types of culture medium and treated with or without rosiglitazone. Transepithelial $\mathrm{Na}^{+}$current was measured and the changes in SGK and Nedd4 expression were determined by immunoblotting. Results: Herein we demonstrate that rosiglitazone stimulates the amiloride-sensitive transepithelial sodium current in Collecting Duct Principal Cells after $3 \mathrm{~h}$ and $24 \mathrm{~h}$ treatment. This activation was dependent of both serum and insulin in culture medium and was mediated by SGK1/Nedd4-2 pathway stimulation. In these conditions, rosiglitazone induced SGK1 expression, Nedd4-2 phosphorylation and thus abolished ubiquitylation and internalization of $\mathrm{ENaC}$ channels. This mechanism explains most of the side effects of thiazolidinediones previously observed in humans and animals. Conclusion: Our data show an increase in transepithelial sodium amiloride-sensitive current induced by a PPARy agonist in presence of serum and insulin, thus confirming some in-vitro and in-vivo experiments while providing explanations for previous conflicting findings.
\end{abstract}

Copyright $@ 2014$ S. Karger AG, Basel 
Chraïbi/Renauld: Rosiglitazone Enhances Sodium Transport in mpkCCD

\section{Introduction}

Peroxisome proliferator-activated receptor gamma (PPAR $\gamma$ ) agonists, such as rosiglitazone (RGZ) and pioglitazone (PGZ), are widely prescribed medications for the treatment of type 2 diabetes mellitus (T2DM). These thiazolidinediones (TZDs) are known to increase insulin sensitivity and thus control glycemia in T2DM patients [1-3]. However, an important clinical limitation for TZDs has been identified in 4-15\% of patients treated with these agents. Thus, both RGZ and PGZ have been associated with an increase in sodium and fluid retention leading to pulmonary edema and congestive heart failure [4-7], consequently leading to these drugs being contraindicated in certain patients [5, 8].

PPAR $\gamma$ agonists promote the heterodimer with retinoid $X$ receptor (RXR) and regulate the transcription of a large number of various genes [9]. PPAR $\gamma$ is expressed in the kidney, more specifically in the aldosterone-sensitive distal nephron (ASDN) [10-13]. ASDN, comprised successively of the distal convoluted tubule (DCT), the connecting tubule and collecting duct (CD), plays an important role in $\mathrm{Na}^{+}$reabsorption primarily through regulation of the epithelial sodium channel (ENaC) [14]. ENaC is a protein complex constituted of three homologous subunits $(\alpha, \beta, \gamma)$ encoded by three different genes [15]. Functional abnormalities of this channel have been linked to disorders in total body $\mathrm{Na}^{+}$homeostasis, blood volume and blood pressure [16]. Thus, ENaC is regulated in a very precise manner, with several factors and mechanisms involved in this regulation. For instance, vasopressin and its analogs bind to $\mathrm{V} 2$ receptors and increase the activity and the translocation of ENaC to the apical membrane from intracellular stores through activation of protein kinase A [17]. Aldosterone and dexamethasone stimulate ENaC activity and expression through different genomic responses [18]. The activated mineralocorticoid (MR) and glucocorticoid receptors (GR) increase mRNA levels of the serum- and glucocorticoids-regulated kinase (SGK1), a serine-threonine kinase which blocks the ubiquitylation process of the channel [19]. SGK1 phosphorylates and inhibits the neural precursor cell-expressed developmentally down-regulated protein 4-2 (Nedd4-2), an E3 ubiquitin ligase inducing internalization and degradation of ENaC [20]. On the other hand, short-term transcriptional regulation of the deubiquitylating enzyme Usp2-45 leads to increased ENaC surface expression and activity. In addition, aldosterone increases the expression of glucocorticoid-induced leucine zipper protein (GILZ) which promotes ENaC plasma membrane localization by inhibition of extracellular signal-regulated kinase (ERK) [21].

PPAR $\gamma$ agonists increase plasma volume and cause weight gain [22]. This TZD-induced weight gain has been shown to be blocked by the collecting duct-specific diuretic amiloride suggesting that $\mathrm{ENaC}$ plays a major role in this effect. This hypothesis remains controversial however and the role of PPAR $\gamma$ in ENaC regulation has yet to be fully resolved [23].

In mouse inner medullary collecting duct (IMCD) cells, PGZ has been shown to increase amiloride-sensitive sodium absorption as well as $\gamma \mathrm{ENaC}$ mRNA expression whereas these effects were inhibited by GW9662, a PPAR $\gamma$ antagonist [22]. Furthermore, treatment of cultured human cortical collecting duct (HCCD) cells with RGZ or PGZ increased SGK1 transcription and activation leading to an increase in $\alpha \mathrm{ENaC}$ protein at the cell surface [12]. PGZ was also proposed to increase SGK1 mRNA and protein levels in mouse kidney. In addition, mice lacking SGK1 failed to present PGZ-induced sodium reabsorption and water retention [24]. Tiwari and colleagues demonstrated an increase of $\gamma \mathrm{ENaC}$ in kidney plasma membrane-enriched fractions in rats treated with PPAR $\gamma$ agonists [25]. Recently, we have shown that RGZ treatment of PPAR $\gamma / \mathrm{ENaC}$-expressing Xenopus oocytes increases $\mathrm{ENaC}$ activity, this stimulation being correlated with an increase in SGK expression [26]. In addition, fluid retention induced by GI262570 treatment, another TZD, has been reported to be correlated with the stimulation of ENaC-Na/K ATPase system in rat [27].

However, other studies suggest that TZD side effects are not mediated by deregulation of amiloride-sensitive sodium reabsorption in ASDN. In mice lacking $\alpha \mathrm{ENaC}$ in the collecting duct ( $\mathrm{Scnn} 1 \mathrm{a}^{\text {loxloxCre}}$ ), RGZ was still able to stimulate amiloride sensitive $\mathrm{Na}^{+}$reabsorption. In native mouse CCD cells, TZD treatment affected neither the number of channels nor their 
Chraïbi/Renauld: Rosiglitazone Enhances Sodium Transport in mpkCCD

opening probability [28]. The authors proposed that the increase in sodium reabsorption was mediated by nonselective cation channels (NSC). In addition, Nofziger and colleagues demonstrated that activation of PPAR $\gamma$ did not directly increase basal or insulin-stimulated sodium transport via $\mathrm{ENaC}$ in either the $\mathrm{mpkCCD}_{\mathrm{c} 14}, \mathrm{M} 1$ or $\mathrm{A} 6$ cortical collecting duct cell lines; moreover no change in SGK1 activity was observed [29]. Most in-vitro TZD treatments have been conducted in absence of serum (FBS) in the culture medium. Retinoic acid and its precursor retinoid are known to be present in FBS [30]. Thus, the presence of FBS in culture medium could improve TZD-mediated PPAR $\gamma$ activation. In the present study, we assessed the role of culture medium composition in the regulation of amiloride-sensitive transepithelial current (Isc) by RGZ. To achieve this, the mpkCCD ${ }_{\text {c14 }}$ cell line was treated with $10 \mu \mathrm{M}$ RGZ in varying culture media for $3 \mathrm{~h}$ and $24 \mathrm{~h}$. Electrophysiological studies showed that serum and insulin are needed to observe RGZ-induced Isc stimulation. Furthermore, as observed by other groups, this activation was correlated with activation of the SGK1/ Nedd4-2 pathway.

\section{Materials and Methods}

\section{Cell culture}

Immortalized mouse cortical collecting duct $\left(\operatorname{mpkCCD}_{\mathrm{c14}}\right)$ principal cells were grown in $4.5 \mathrm{~cm}^{2}$ permeable polyester filters with $0.4 \mu \mathrm{m}$ pore size (Greiner-Bio-One, Germany) in complete medium containing DMEM low glucose/Ham's F12 50:50 supplemented with: insulin (5 $\mu \mathrm{g} / \mathrm{ml})$, dexamethasone (50 nM), sodium selenate (60 nM), transferrin (5 $\mathrm{gg} / \mathrm{ml})$, T3 (1 nM), EGF (10 ng/ml), Hepes (20 mM), Fetal Bovine Serum (FBS) (2\%), glucose (2 g/l) and penicillin/streptomycin (100 IU-100 $\mu \mathrm{g} / \mathrm{ml}$ respectively). When transepithelial resistance reached 1-1.2 k $\Omega . \mathrm{cm}^{2}$ (4-5 days after seeding), cells were maintained 16$18 \mathrm{~h}$ in complete medium or hormone-free medium (HFM). The HFM medium contains only DMEM low glucose/Ham's F12 50:50 supplemented with Hepes (20 mM) and penicillin/streptomycin (100 IU-100 $\mu \mathrm{g} / \mathrm{ml}$ respectively). In selected experiments, cells were maintained in modified medium as described in the Results section, namely HFM with or without FBS, HFM with FBS and insulin, and complete medium without insulin. Cell lines were then treated with $1 \mu \mathrm{M}$ dexamethasone, $10 \mu \mathrm{M}$ RGZ or vehicle (DMSO) for $3 \mathrm{~h}$ and $24 \mathrm{~h}$.

\section{Transepithelial current measurement}

Transepithelial voltage (Vte) and resistance (Rte) of each filter were measured under sterile conditions with an EndOhm-6 coupled to an EVOM² (WPI, Sarasota, FL, USA) before and after treatment. Briefly, Vte was measured by means of a set of $2 \mathrm{Ag}-\mathrm{AgCl}$ electrodes and determined with the apical electrode as reference. Rte was measured by passage of current through the cell monolayer and measurement of the resulting voltage gradient across the cells. The transepithelial current (Isc) was calculated using Ohm's law. $10 \mu \mathrm{M}$ amiloride was added in the apical compartment to determine the magnitude of ENaC-mediated sodium transport across the cell monolayer.

\section{Western blot analysis}

After $3 \mathrm{~h}$ and $24 \mathrm{~h}$ of the various treatments, cells were lysed for $10 \mathrm{~min}$ at $4^{\circ} \mathrm{C}$ in $350 \mu \mathrm{l}$ of buffer containing: $100 \mathrm{mM} \mathrm{NaCl}, 50 \mathrm{mM}$ Tris- $\mathrm{HCl}$ [pH 7.5], $5 \mathrm{mM} \mathrm{Na}$-EDTA, $40 \mathrm{mM} \beta$-glycerophosphate, 50 $\mathrm{mM}$ NaF, 5\% glycerol, 1\% Triton X-100, $200 \mu \mathrm{M}$ sodium orthovanadate and the Complete ${ }^{\mathrm{TM}}$ EDTA-free $^{-}$ protease inhibitor (Roche Diagnostics, Laval, Canada). Cell homogenates were then transferred in a 1.5 $\mathrm{ml}$ tube and centrifuged $10 \mathrm{~min}, 10000 \mathrm{x} \mathrm{g}$ at $4^{\circ} \mathrm{C}$. Total proteins in the supernatant were collected and their concentration determined using the Bradford protein assay method and stored at $-80^{\circ} \mathrm{C} .15 \mu \mathrm{g}$ of total proteins were solubilized in Laemmli sample buffer containing: $62.5 \mathrm{mM}$ Tris- $\mathrm{HCl}$ [pH6.8], 10\% glycerol, $5 \% \beta$-mercaptoethanol, $2.3 \%$ SDS and $0.1 \%$ bromophenol blue. Samples were subjected to SDS-PAGE and Western blot analysis and transferred onto PVDF membranes (Perkin Elmer, Woodbridge, ON, Canada). Membranes were sectioned between 72 and $100 \mathrm{kDa}$ according to the molecular weight of the proteins of interest: SGK1 (68 kDa) and $\alpha$-tubulin (55 kDa); total and phosphorylated form of Nedd4-2 (112 kDa). Each membrane section was blocked for $2 \mathrm{~h}$ at RT in TBS containing $0.1 \%$ Tween-20 (TBST) and 5\% 
Chraïbi/Renauld: Rosiglitazone Enhances Sodium Transport in mpkCCD

skimmed milk (except for the detection of the phosphorylated form of Nedd4-2, where milk was replaced by $5 \%$ fatty acid-free BSA) and then hybridized with appropriate primary and secondary antibodies. The antibodies used were rabbit polyclonal anti-SGK1 (1:1000, Abcam, Cambridge, MA), rabbit polyclonal antiNedd4-2 (1:1000, Abcam, Cambridge, MA), rabbit polyclonal anti-Nedd4-2 (phoso S328) (1:1000, Abcam, Cambridge, MA), rabbit monoclonal anti- $\alpha$-tubulin (1:1000, Cell Signaling) and HRP-linked sheep antirabbit IgG secondary antibody (1:5000, AbD Serotec, Raleigh, NC). Primary antibodies were diluted in blocking solution and hybridized overnight at $4^{\circ} \mathrm{C}$. Membranes were washed five times (10 min each) in TBST and hybridized (1h at RT with gentle shaking) with the appropriate HRP-conjugated secondary antibody diluted in blocking solution. After five washes in TBST, proteins were subjected to Western Lightning Chemiluminescence Reagent Plus (Perkin-Elmer, Woodbridge, Canada) and detected on Amersham Hyperfilm ECL (GE Healthcare). After detection, membranes were stained with Ponceau S (Sigma-Aldrich, Oakville, Ontario, Canada), to confirm protein loading equivalence. Densitometric analysis of the protein of interest normalized with $\alpha$-tubulin was performed with ImageJ software [31].

\section{Antibody stripping protocol}

After SGK1 and p-Nedd4-2 detection, PVDF membranes were incubated 15 min at $55^{\circ} \mathrm{C}$ in stripping solution containing: $62.5 \mathrm{mM}$ Tris- $\mathrm{HCl}, \mathrm{pH} 6.8 ; 2 \%$ SDS; $0.8 \% \beta$-mercaptoethanol. Membranes were washed $2 \mathrm{~h}$ with tap water and allowed to equilibrate for $15 \mathrm{~min}$ in TBST. To ensure antibodies were removed from proteins, membranes were incubated in the blocking solution for $1 \mathrm{~h}$, hybridized with the appropriate secondary antibody and proteins revealed on ECL film. Membranes were then processed for Nedd4-2 and $\alpha$-tubulin detection.

Chemicals and antibodies

Culture media, FBS, penicillin/streptomycin, Hepes, transferrin and D-glucose were purchased from Wisent (St Bruno, QC, Canada). RGZ was purchased from Molekula (St Louis, MO, USA). All other chemicals were purchased from Sigma (Oakville, ON, Canada). Rabbit polyclonal anti SGK1, Nedd4-2 and p-Nedd4-2 were purchased from Abcam (Cambridge, MA, USA). Rabbit monoclonal anti- $\alpha$-tubulin was purchased from Cell Signalling/NEB (Pickering, ON, Canada).

\section{Statistical analysis}

Data are presented in the text and figures as mean \pm SEM with differences considered statistically significant at the 95\% confidence level $(\mathrm{P}<0.05)$. Two-way ANOVA with Bonferroni multiple comparison post tests as indicated in figure legends were performed using GraphPad Prism version 5.02 for Windows (GraphPad Software, San Diego, CA, USA).

\section{Results}

Effect of RGZ on amiloride-sensitive $\mathrm{Na}^{+}$transport in mpkCCDc14 cells cultured in HFM and complete medium

We first tested whether culture conditions could alter the effect of RGZ stimulation on Isc. To achieve this, electrophysiological measurements of transepithelial $\mathrm{Na}^{+}$current were performed in monolayers of $\mathrm{mpkCCD}_{\mathrm{c} 14}$ cells, with strong transepithelial resistance (1-1.2 $\mathrm{k} \Omega . \mathrm{cm}^{2}$ ), cultured in either HFM or complete medium. Thereafter, the epithelial cell line was treated with DMSO (vehicle), RGZ $(10 \mu \mathrm{M})$ or Dexamethasone (Dexa) $(1 \mu \mathrm{M})$ for $3 \mathrm{~h}$ and $24 \mathrm{~h}$. Dexamethasone was used as positive control in all experiments. Its effect on amiloridesensitive current has been extensively studied and well characterized in the epithelial cell line [32].

Basal values of Isc in HFM or complete medium were $15.68 \pm 0.48 \mu \mathrm{A}(\mathrm{n}=54)$ and $28.37 \pm 0.79 \mu \mathrm{A}(\mathrm{n}=65)$, respectively. Amiloride $(10 \mu \mathrm{M})$ was added to the apical membrane at the end of the experiments to confirm that the transepithelial current was mediated by ENaC. In both groups, amiloride strongly decreased sodium current showing that the majority of basal $\mathrm{Na}^{+}$transport in mpkCCD ${ }_{\text {c14 }}$ cells is amiloride-sensitive (Fig. 1, Table 1). 
Chraïbi/Renauld: Rosiglitazone Enhances Sodium Transport in mpkCCD

Table 1. Normalized residual Isc after $24 \mathrm{~h}$ treatment with DMSO, dexamethasone $(1 \mu \mathrm{M})$ or RGZ $(10 \mu \mathrm{M})$. Amiloride $(10 \mu \mathrm{M})$ was added to the apical membrane at the end of experiment to determine ENaC implication in the current

\begin{tabular}{cclcc}
\hline & basal values of Isc $(\mu A)$ & \multicolumn{2}{c}{ normalized Isc amiloride resistant after treatment $(24 \mathrm{~h})$} \\
Culture condition & \multicolumn{1}{c}{ DMSO (T0) } & DMSO (T24) + am & Dexa (T24) + am & RGZ (T24) + am \\
\hline HFM & $15.68 \pm 0.48(\mathrm{n}=54)$ & $0.10 \pm 0.01(\mathrm{n}=10)$ & $0.11 \pm 0.03(\mathrm{n}=9)$ & $0.09 \pm 0.02(\mathrm{n}=9)$ \\
Complete medium & $28.37 \pm 0.79(\mathrm{n}=65)$ & $0.07 \pm 0.03(\mathrm{n}=9)$ & $0.12 \pm 0.02(\mathrm{n}=10)$ & $0.09 \pm 0.03(\mathrm{n}=11)$ \\
HFM + FBS & $19.10 \pm 0.21(\mathrm{n}=41)$ & $0.08 \pm 0.03(\mathrm{n}=9)$ & $0.12 \pm 0.02(\mathrm{n}=6)$ & $0.08 \pm 0.04(\mathrm{n}=7)$ \\
Complete medium - FBS & $17.22 \pm 0.98(\mathrm{n}=46)$ & $0.07 \pm 0.02(\mathrm{n}=9)$ & $0.13 \pm 0.03(\mathrm{n}=7)$ & $0.08 \pm 0.02(\mathrm{n}=7)$ \\
Complete medium - ins & $31.54 \pm 0.67(\mathrm{n}=43)$ & $0.08 \pm 0.02(\mathrm{n}=9)$ & $0.12 \pm 0.04(\mathrm{n}=7)$ & $0.08 \pm 0.02(\mathrm{n}=7)$ \\
HFM + FBS + ins & $25.05 \pm 1.74(\mathrm{n}=49)$ & $0.12 \pm 0.02(\mathrm{n}=9)$ & $0.10 \pm 0.01(\mathrm{n}=8)$ & $0.10 \pm 0.02(\mathrm{n}=8)$ \\
\hline
\end{tabular}

A

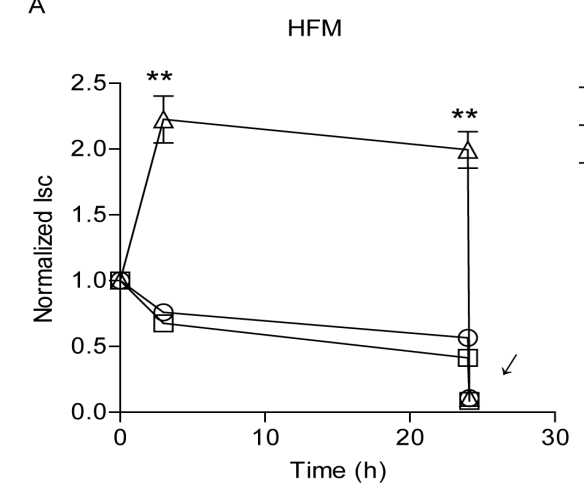

B

$$
\begin{array}{ll}
\ominus & \text { DMSO } \\
\square & \text { RGZ }
\end{array}
$$$$
\triangle \text { Dexa }
$$

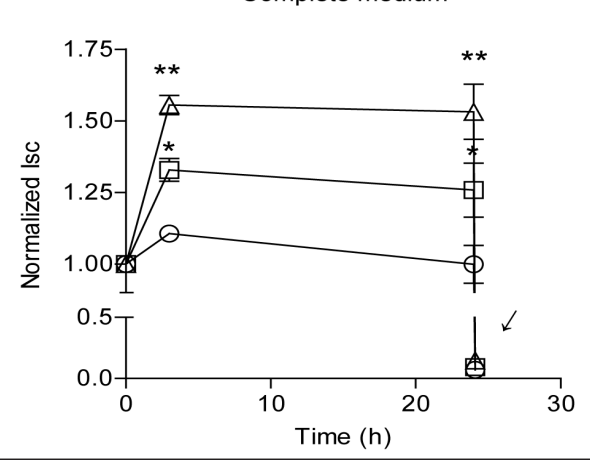

Fig. 1. Effect of RGZ on amiloride-sensitive current (Isc) measured in mpkCCD ${ }_{\text {c14 }}$ cells. Cells were treated with dexamethasone, rosiglitazone or DMSO (vehicle) for $3 \mathrm{~h}$ or $24 \mathrm{~h}$ in hormone-free medium (HFM) (A) or in complete medium (B). Arrow indicates the application of amiloride $(10 \mu \mathrm{M})$. Values were normalized to means of control measurements (NT: non-treated cells) and represent means \pm SEM of 5 and 7 separate experiments for HFM and complete medium respectively. Each experiment contains 2 to 3 filters per condition. *: $\mathrm{P}<0.001$; **: $\mathrm{P}<0.0001$ compared to DMSO group, 2-way ANOVA with Bonferroni post-test. In certain instances, SEM is smaller than the size of the symbol representing the different treatment.

Isc in control experiments or after treatment was normalized to starting levels. As shown in Figure 1, RGZ treatment did not produce any significant change in Isc in HFM condition. Treatment with $1 \mu \mathrm{M}$ Dexa produced a $2.22 \pm 0.18$ and $1.99 \pm 0.13$ fold increase in Isc after $3 \mathrm{~h}$ and $24 \mathrm{~h}$, respectively $(\mathrm{n}=10)$. However, in complete medium, $10 \mu \mathrm{M}$ RGZ treatment induced a significant increase in Isc compared to the DMSO group: $1.33 \pm 0.03$ fold after $3 \mathrm{~h}$ and 1.26 \pm 0.09 fold after $24 \mathrm{~h}$ treatment (n=19; Fig. 1B). Dexa generated a $1.55 \pm 0.03$ fold and $1.53 \pm$ 0.09 fold increase in the same time intervals $(\mathrm{n}=17)$.

Western blot analyses were conducted to assess whether the SGK1 pathway was involved in this activation. Protein expression of SGK1 protein and phosphorylation of Nedd4-2 as a marker of SGK1 activity were measured. Fig. 2A and B show representative Western blots of SGK1, Nedd4-2 and p-Nedd4-2 expression in HFM and complete medium respectively, treated for $3 \mathrm{~h}$ and $24 \mathrm{~h}$ with DMSO, Dexa $(1 \mu \mathrm{M})$ or RGZ $(10 \mu \mathrm{M})$. SGK1 expression (Fig 2C-D) was stimulated by Dexa in both conditions compared to untreated cells (NT) while RGZ increased the expression of SGK1 only in the complete medium group. In HFM condition (Fig 2C), the Dexa-induced increase was $1.26 \pm 0.03$ fold and $1.18 \pm 0.03$ fold $3 \mathrm{~h}$ and $24 \mathrm{~h}$ after treatment, respectively. In the complete medium group, Dexa-induced stimulation was $1.20 \pm 0.04$ fold and $1.33 \pm 0.06$ fold. Interestingly, in this medium, RGZ treatment induced an increase in SGK expression of $1.33 \pm 0.09$ fold and $1.33 \pm 0.05$ fold after $3 \mathrm{~h}$ and $24 \mathrm{~h}$, respectively. Thus, these results are consistent with the effect of RGZ on ENaC function observed in Figure $1 \mathrm{~A}-\mathrm{B}$. In both culture conditions, the total expression of Nedd4-2 remained unaffected regardless of 
Fig. 2. Effect of RGZ on the SGK1/Nedd4-2 pathway in mpkCCD $_{\text {c14 }}$ cells. Representative Western blot experiments showing the expression of SGK1, Nedd4-2 and p-Nedd4-2 normalized with $\alpha$-tubulin in HFM (A) and in complete medium (B) after treatment of cells with dexamethasone, rosiglitazone or DMSO (vehicle) for $3 \mathrm{~h}$ or $24 \mathrm{~h}$. Densitometric data were normalized to means of control measurements (NT: nontreated cells) for SGK1 (C-D), Nedd4-2 (E-F) and p-Nedd4-2 (G$\mathrm{H})$ and represent the means \pm SEM of 5 separate experiments for each culture medium. Each experiment contains 2 to 3 filters per condition. *: $\mathrm{P}<0.05$; $* *<0.01$, compared to DMSO group, 2-way ANOVA with Bonferroni post-test.

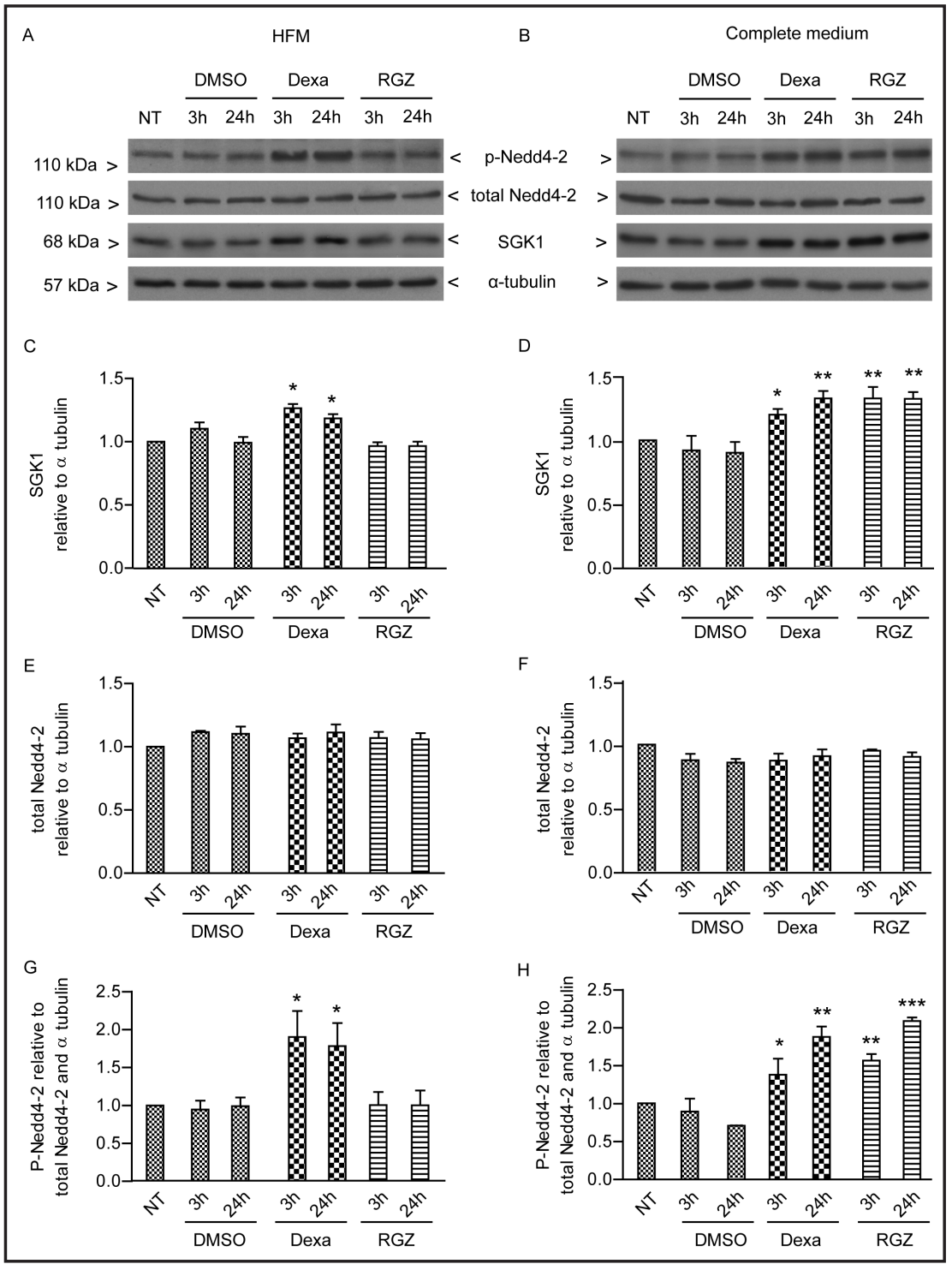

treatment (Fig. 2 E-F). Nevertheless, the phosphorylated form of Nedd4-2 was dependent on both treatment and the culture medium. As shown in Fig. 2A-B (top panel), Dexa induced an increase in the intensity of the band at 110 KDa confirming the phosphorylation of Nedd4-2. This result is concordant with previous studies showing a similar effect of Dexa treatment in pancreatic duct adenocarcinoma cells [32]. In the present experiments, Dexa-induced phosphorylation was respectively $1.90 \pm 0.34$ fold and $1.78 \pm 0.30$ fold after $3 \mathrm{~h}$ and $24 \mathrm{~h}$ in the HFM group and $1.39 \pm 0.21$ fold and $1.88 \pm 0.13$ fold after $3 \mathrm{~h}$ and $24 \mathrm{~h}$, respectively, in the complete medium group. RGZ-induced phosphorylation of Nedd4-2 was $1.57 \pm 0.08$ fold and $2.09 \pm 0.05$ fold after $3 \mathrm{~h}$ and $24 \mathrm{~h}$ in the complete medium group (Fig. $2 \mathrm{G}-\mathrm{H}$ ). The above data hence indicate that activation of Isc by RGZ is likely correlated with stimulation of the SGK1/ Nedd4-2 pathway.

Role of FBS in RGZ-induced amiloride-sensitive $\mathrm{Na}^{+}$transport stimulation

PPAR $\gamma$ transcriptional activity is known to be dependent on heterodimerization with RXR. Retinoic acid, a RXR ligand, and its precursor have been shown to be present in FBS [30]. In order to verify whether FBS played a role in RGZ-induced stimulation of Isc and SGK1/Nedd4-2 pathway in our model, mpkCCD $_{\text {c14 }}$ cells were maintained $16 \mathrm{~h}-18 \mathrm{~h}$ in two different culture media: HFM supplemented with FBS or a complete medium deprived of 
A

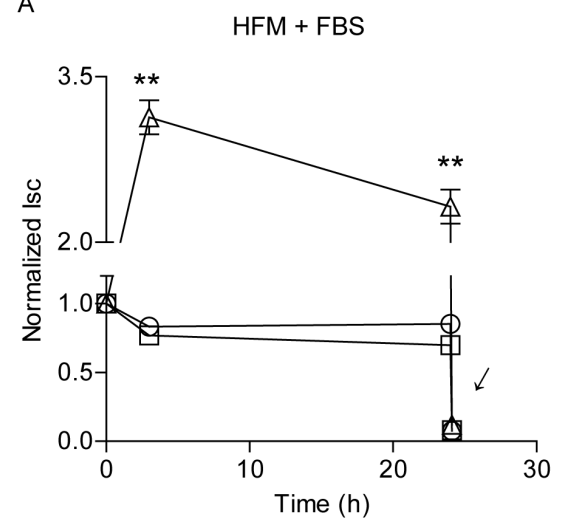

B

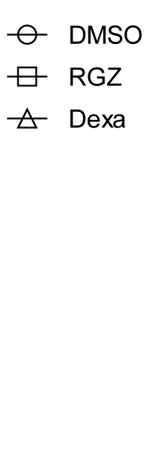

Complete medium - FBS

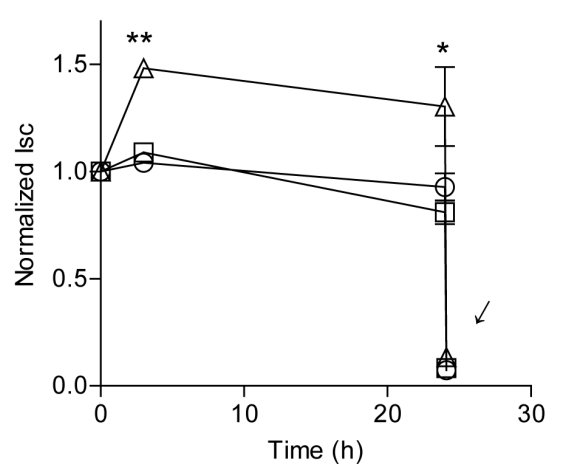

Fig. 3. Effect of fetal bovine serum (FBS) in RGZ-induced activation of Isc in mpkCCD ${ }_{\text {c14 }}$ cells. Cells were treated with dexamethasone, rosiglitazone or DMSO (vehicle) for $3 \mathrm{~h}$ or $24 \mathrm{~h}$ in HFM supplemented with FBS (A) or in complete medium depleted of FBS (B). Arrows indicate amiloride application $(10 \mu \mathrm{M})$. Values were normalized to means of control measurements (NT: non-treated cells) and represent the means \pm SEM of 5 separate experiments for each culture medium. Each experiment contains 2 filters per condition. *: $\mathrm{P}<0.001$. **: P<0.0001, compared to DMSO group, 2-way ANOVA with Bonferroni post-test.

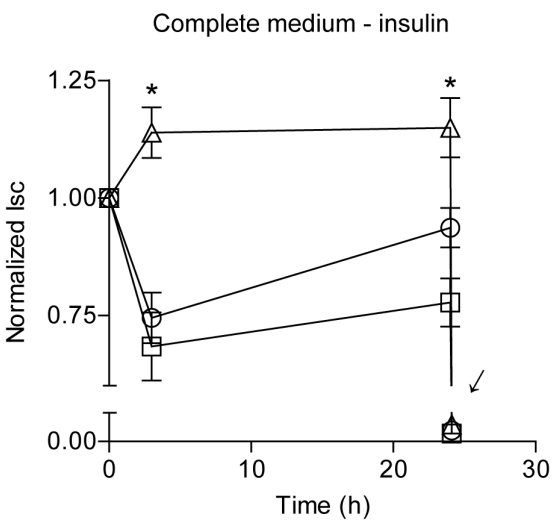

B

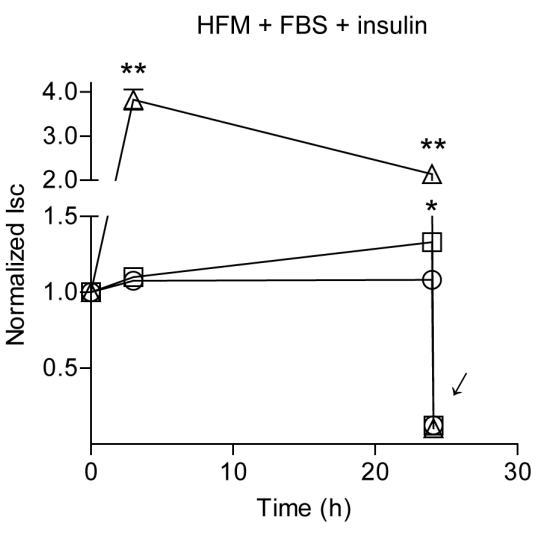

Fig. 4. Effect of insulin in RGZ-induced activation of Isc in mpkCCD ${ }_{c 14}$ cells. Cells were treated with dexamethasone, rosiglitazone or DMSO (vehicle) for $3 \mathrm{~h}$ or $24 \mathrm{~h}$ in complete medium depleted of insulin (A) or in HFM supplemented with FBS and insulin (B). Arrows indicate amiloride application (10 $\mu$ M). Values were normalized to means of control measurements (NT: non-treated cells) and represent the means \pm SEM of 5 separate experiments for each culture medium. Each experiment contains 2 filters per condition. ${ }^{* *}$ : $\mathrm{P}<0.0001$; *: $\mathrm{P}<0.001$, compared to DMSO group, 2-way ANOVA with Bonferroni post-test.

FBS. Basal values of Isc (Isc values before treatment) were $19.10 \pm 0.21 \mu \mathrm{A}(\mathrm{n}=41)$ and 17.22 $\pm 0.98 \mu \mathrm{A}$, respectively $(\mathrm{n}=46)$. As observed previously, transepithelial sodium current was strongly sensitive to amiloride in both culture conditions (Fig. 3 and Table 1).

In HFM supplemented with FBS (Fig. 3A), Dexa produced a $3.13 \pm 0.15$ and $2.32 \pm 0.15$ fold increase in Isc after $3 \mathrm{~h}$ and $24 \mathrm{~h}$, respectively $(\mathrm{n}=10)$ whereas in complete medium deprived of FBS (Fig. 3B), Dexa-induced stimulations were $1.48 \pm 0.04$ and $1.30 \pm 0.18(\mathrm{n}=10)$. Surprisingly, no effect of RGZ could be detected in the two different culture media (Fig. 3A-B). Previously, other data reported that PPAR $\gamma$ agonists do not increase $\mathrm{ENaC}$ activity in different cell types $[29,33]$. In these latter studies, cells were serum-starved overnight and during treatment with PPAR $\gamma$ agonists. It thus appeared of interest to consider the hypothesis that FBS is necessary but not sufficient for RGZ-induced Isc stimulation. 
Fig. 5. Effects of fetal bovine serum (FBS) and insulin on the activation of the SGK1/Nedd4-2 pathway induced by RGZ. A: representative Western blot experiments showing SGK1, Nedd42 and p-Nedd4-2 normalized with $\alpha$-tubulin in HFM supplemented with FBS and insulin. Densitometric data were normalized to means of control measurements (NT: non-treated cells) for SGK1 (B), Nedd4-2 (C) and p-Nedd4-2 (D) and represent the means \pm SEM of 5 separate experiments for each culture medium. Each experiment contains 2 to 3 filters per condition. *: $\mathrm{P}<0.01$; ***: $\mathrm{P}<0.001$, compared to DMSO group, 2-way ANOVA with Bonferroni post-test.

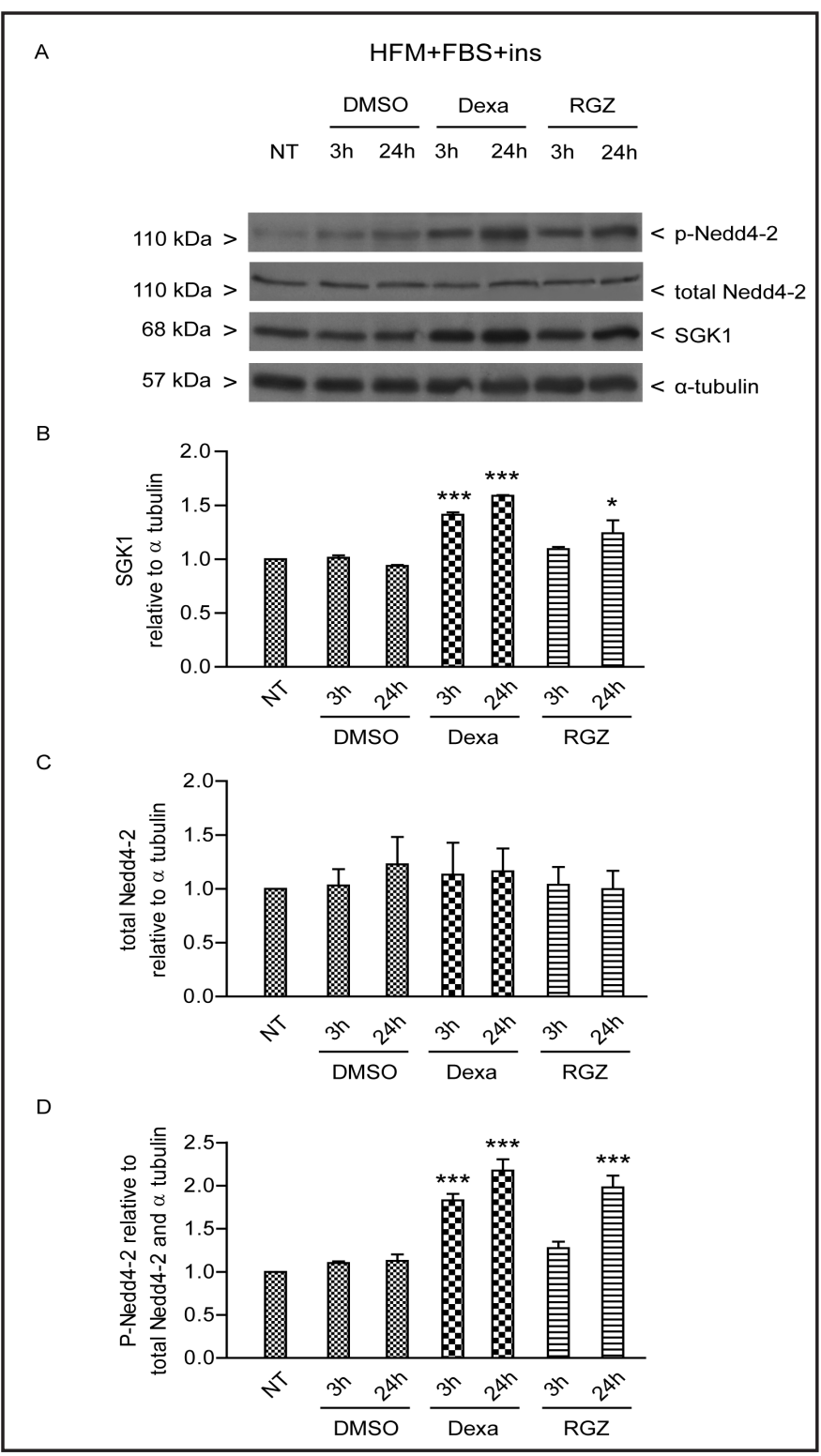

Role of insulin in RGZ-induced amiloride-sensitive $\mathrm{Na}^{+}$transport stimulation

It has long been known that insulin stimulates renal $\mathrm{Na}^{+}$reabsorption. Several groups demonstrated that this effect was due to an activation of ENaC, likely by an increase in its Po [34-38]. Recently, Pavlov and colleagues have shown that insulin increases amiloridesensitive $\mathrm{Na}^{+}$current in mpkCCD cells. This effect was partially diminished by a PPAR $\gamma$ antagonist. On the other hand, PGJ2 (a PPAR $\gamma$ agonist) was not able to regulate the amount of $\mathrm{Na}^{+}$elicited by insulin [33]. However, the role of insulin in the activation of PPAR $\gamma$ has not been investigated. To determine the effect of insulin in this activation and its effect on amiloride-sensitive $\mathrm{Na}^{+}$transport, $\mathrm{mpkCCD}_{\mathrm{c} 14}$ cells were first cultured in insulin-depleted complete medium 16-18h before DMSO, Dexa or RGZ treatment. Basal value of Isc was $31.54 \pm 0.67 \mu \mathrm{A}(\mathrm{n}=43)$. In this condition, Dexa produced an $1.14 \pm 0.05$ and $1.15 \pm 0.06$ fold increase in Isc after $3 \mathrm{~h}$ and $24 \mathrm{~h}$ treatment, respectively $(\mathrm{n}=8)$ while RGZ had no stimulatory effect on this current (Fig. 4A). These same treatments were subsequently performed in cells cultured in HFM supplemented with $2 \%$ FBS and $5 \mu \mathrm{g} / \mathrm{ml}$ insulin for $16-18 \mathrm{~h}$. Before treatment, Isc was $25.05 \pm 1.74 \mu \mathrm{A}(\mathrm{n}=49)$. As shown in Fig. 4B, Dexa strongly stimulated Isc ( $3.82 \pm 0.23$ and $2.14 \pm 0.13$ fold after $3 \mathrm{~h}$ and $24 \mathrm{~h}$, respectively; $\mathrm{n}=10$ ) while RGZ produced 
a $1.10 \pm 0.05$ and $1.33 \pm 0.06$ fold increase in Isc after $3 \mathrm{~h}$ and $24 \mathrm{~h}$ stimulation $(\mathrm{n}=10)$. The addition of amiloride in the apical compartment completely abolished the sodium current (Fig. 4 and Table 1).

SGK1 and Nedd4-2 expression as well as the phosphorylated form of Nedd4-2 were assessed by Western blot (Fig. 5). Treatment with $1 \mu \mathrm{M}$ Dexa produced a $1.41 \pm 0.02$ and a $1.59 \pm 0.01$ fold increase after $3 \mathrm{~h}$ and $24 \mathrm{~h}$ treatment. Dexa-induced phosphorylation of Nedd4-2 was $1.83 \pm 0.07$ and $2.17 \pm 0.13$ fold after $3 \mathrm{~h}$ and $24 \mathrm{~h}$ treatment. RGZ produced a significant stimulation of SGK1 expression and Nedd4-2 phosphorylation only after 24h, with increases of $1.24 \pm 0.12$ fold for SGK1 expression and $1.98 \pm 0.14$ fold for Nedd4-2 phosphorylation. These results indicate that insulin plays a major role in RGZ-dependent Isc and SGK1/Nedd4-2 pathway stimulation.

\section{Discussion}

TZDs are currently used to treat type 2 diabetes mellitus, however many studies have shown that TZD-induced fluid retention observed in T2DM patients is an unwanted side effect mediated by PPAR $\gamma$ in the distal nephron, often leading to the discontinuation of therapy [22, 39-41]. During the past decade, several studies have provided important information regarding this effect although its molecular mechanisms are not clearly understood and remain controversial. Song and colleagues reported that chronic 3-day administration of RGZ to Sprague-Dawley rats significantly reduced urine volume and sodium excretion suggesting that TZD-induced edema is caused by a positive sodium balance. In particular, the authors noted that the rise in sodium and water retention was associated with an increase in the renal abundance of Na-K-2Cl contransporter, the $\alpha-1$ subunit of $\mathrm{Na}^{+} / \mathrm{K}^{+}$ATPase, NHE3, and the isoforms 2 and 3 of aquaporins [42]. In addition, clinical studies have suggested that the fluid-retaining effect of TZDs is more frequent in postmenopausal women. Yoshioka and colleagues reported that pioglitazone decreased urinary sodium excretion only in ovariectomized female Zucker obese rats [43]. Furthermore, it was shown that collecting duct-specific deletion of PPAR $\gamma$ blocks TZD-induced fluid retention in mice [41]. Similarly, Guan et al. were able to counteract this water retention by using amiloride, suggesting that ENaC is implicated in the side effects of TZDs [22]. Zhang et al. reported that rosiglitazone stimulated sodium transport in primary cultures of CD cells expressing PPAR $\gamma$ but not in cells lacking this receptor [41]. On the other hand, it was shown that PPAR $\gamma$ antagonists decreased Isc in mpkCCD $_{\text {c14 }}$ cells and that an overexpression of the receptor stimulated the amiloride sensitive current in CHO cells. In contrast, RGZ had no effect on sodium transport in these cells [33]. Our recent findings have shown that RGZ treatment of PPAR $\gamma / \mathrm{ENaC}$ expressing Xenopus oocytes increases ENaC activity [26]. This activation was abolished by the PPAR $\gamma$ antagonist GW9662. Furthermore, Xenopus PPAR $\gamma$ was undetectable in uninjected oocytes, strengthening the PPAR $\gamma$ dependence of the increase in RGZ-induced sodium current. In the present work, we focused our study on the role of culture medium components in RGZ-induced sodium amiloride-sensitive transport activation in a cortical collecting duct cell line. Our results support the in vivo data described above and confirm the importance of the composition of culture medium in RGZ-induced sodium current increase. Results show that RGZ treatment of mpkCCD ${ }_{c 14}$ cells cultured in complete medium produced an increase in sodium Isc. On the other hand, this effect was not detected in culture medium without serum. Of note, similar results previously reported by many groups who proposed that TZDs do not stimulate sodium transport were obtained in studies carried out in serum-starved cell models during 18h-24h before and during TZD treatment. Indeed, Nofziger and colleagues demonstrated that activation of PPAR $\gamma$ with either PGZ or GW7845 did not directly enhance basal or insulin-stimulated sodium transport via ENaC in three cortical collecting duct cell lines [29]. Moreover, Wilson and coworkers conducted similar experiments and concluded that PGZ and troglitazone (TGZ) had no discernible effect on transepithelial sodium absorption in distal nephron cells and distal airway epithelial cells 
[3]. Vallon and colleagues also recently reported that TZD side effects were not mediated by ENaC [28] while Borstimg et al. concluded that the PPAR $\gamma$ agonists repressed the expression of this channel [44]. Therefore, how can the present findings be reconciled with the above reported data proposing that TZD treatment is not associated with stimulation of $\mathrm{ENaC}$ expression leading to increased sodium and fluid retention? It is clear that the PPARs regulate gene transcription by binding to PPAR response elements (PPRE) of target genes and heterodimerization with the retinoid $\mathrm{X}$ receptor (RXR). Thus, RXR is a required partner for PPAR activity [45]. Furthermore, RXR expression has been shown in the nephron [13] in which activation of this receptor is provided by 9-cis retinoic acid, a component of FBS [30]. Therefore, it is most likely that stimulation of ENaC activity by PPAR $\gamma$ agonists obtained in our studies and described by other investigators $[12,22,26]$ may in part be due to the activation of RXR by retinoic acid.

It has previously been shown that PPAR $\gamma$ antagonists decrease insulin-stimulated amiloride-sensitive sodium transport. However activation of PPAR $\gamma$ failed to enhance this transport $[29,33]$. Interestingly, our results demonstrate that RGZ was able to stimulate Isc in the presence of insulin, thus confirming that this hormone plays a major role in TZD-induced sodium retention. Moreover, our finding support previously reported data by Werman and colleagues showing that PPAR $\gamma$ transcriptional activation is regulated by insulin [46]. Activation of these nuclear receptors is dependent on several coactivators and signaling pathways. Kim et al. have shown that phosphoinositide-3 kinase (PI3K) activation stimulates PPAR $\gamma$ in the 3T3 cell line [47]. Moreover, the phosphoinositide dependent kinase1 (PDK1) has been shown to be a molecular partner for PPAR $\gamma$ in the same model [48]. Given that insulin stimulates PI3K and the downstream kinase PDK1, it may therefore play a determinant role for PPAR $\gamma$ activation in $\mathrm{mpkCCD}_{\mathrm{c} 14}$ cells.

Using gene-targeted mice lacking SGK1, Artunc et al. [24] observed that RGZ treatment increases renal SGK1 expression suggesting that the SGK1 is another important molecular partner in ENaC regulation by PPAR $\gamma$ agonists. Furthermore, it was shown that TZDs stimulate SGK1 transcription through PPAR $\gamma$ activation, leading to increased SGK1 activity followed by an increase in the expression of $\alpha$ or $\gamma$ subunits of $\operatorname{ENaC}[12,22,25]$. On the other hand, it is well know that SGK1 phosphorylates Nedd4-2 and favors the reduction of the ubiquitination of ENaC, resulting in an increase in sodium transport [20,49-51]. In accordance with these data, our study shows that RGZ-induced amiloride-sensitive sodium activation is associated with stimulation of the expression of SGK1 as well as its activity.

In summary, PPAR $\gamma$-agonists have been associated with sodium and fluid retention. However, the precise mechanisms underlying these effects remain controversial. We have recently shown that RGZ increases ENaC activity in Xenopus oocytes [26]. With the present data, we demonstrate that RGZ-induced stimulation of the amiloride-sensitive sodium current in mpkCCD ${ }_{\text {c14 }}$ cells is serum and insulin dependent. Our experiments provide explanations for the controversy surrounding the effects of these agonists and support the notion that this regulation is mediated by the SGK1/Nedd4-2 pathway.

\section{Acknowledgements}

We would like to sincerely thank Dr. Alain Vandewalle from INSERM U773, Paris, France for the $\mathrm{mpkCCD}_{\mathrm{cl} 4}$ cell line and Mr Jean Lainé, from Department of Physiology and Biophysics, FMSS, Sherbrooke for technique assistance.

This work was supported by the Canada Foundation for Innovation and Kidney Foundation of Canada grant to A. Chraibi (KFOC120029). S. Renauld was Ph.D. student in the laboratory of A. Chraibi. 


\begin{tabular}{|c|c|c|}
\hline Cellular Physiolosy & Cell Physiol Biochem 2014;33:581-593 & \\
\hline and Biochemistry & $\begin{array}{l}\text { DOI: } 10.1159 / 000358636 \\
\text { Published online: February } 25,2014\end{array}$ & $\begin{array}{l}\text { O } 2014 \text { S. Karger AG, Basel } \\
\text { www.karger.com/cpb }\end{array}$ \\
\hline
\end{tabular}

\section{References}

1 Forman BM, Tontonoz P, Chen J, Brun RP, Spiegelman BM, Evans RM: 15-Deoxy-delta 12, 14-prostaglandin J2 is a ligand for the adipocyte determination factor PPAR gamma. Cell 1995;83:803-812.

-2 Fuchtenbusch M, Standl E, Schatz H: Clinical efficacy of new thiazolidinediones and glinides in the treatment of type 2 diabetes mellitus. Exp Clin Endocrinol Diabetes 2000;108:151-163.

-3 Willson TM, Lambert MH, Kliewer SA: Peroxisome proliferator-activated receptor gamma and metabolic disease. Annu Rev Biochem 2001;70:341-367.

4 Mudaliar S, Chang AR, Henry RR: Thiazolidinediones, peripheral edema, and type 2 diabetes: incidence, pathophysiology, and clinical implications. Endocr Pract 2003;9:406-416.

-5 Nesto RW, Bell D, Bonow RO, Fonseca V, Grundy SM, Horton ES, Le Winter M, Porte D, Semenkovich CF, Smith S, Young LH, Kahn R: Thiazolidinedione use, fluid retention, and congestive heart failure: a consensus statement from the American Heart Association and American Diabetes Association. October 7, 2003. Circulation 2003;108:2941-2948.

6 Niemeyer NV, Janney LM: Thiazolidinedione-induced edema. Pharmacotherapy 2002;22:924-929.

7 Thomas ML, Lloyd SJ: Pulmonary edema associated with rosiglitazone and troglitazone. Ann Pharmacother 2001;35:123-124.

8 Vasudevan AR, Balasubramanyam A: Thiazolidinediones: a review of their mechanisms of insulin sensitization, therapeutic potential, clinical efficacy, and tolerability. Diabetes Technol Ther 2004;6:850-863.

-9 Hauner H: The mode of action of thiazolidinediones. Diabetes Metab Res Rev 2002;18:S10-15.

10 Fajas L, Auboeuf D, Raspe E, Schoonjans K, Lefebvre AM, Saladin R, Najib J, Laville M, Fruchart JC, Deeb S, Vidal-Puig A, Flier J, Briggs MR, Staels B, Vidal H, Auwerx J: The organization, promoter analysis, and expression of the human PPARgamma gene. J Biol Chem 1997;272:18779-18789.

11 Guan Y, Zhang Y, Davis L, Breyer MD: Expression of peroxisome proliferator-activated receptors in urinary tract of rabbits and humans. Am J Physiol 1997;273:F1013-1022.

-12 Hong G, Lockhart A, Davis B, Rahmoune H, Baker S, Ye L, Thompson P, Shou Y, O'Shaughnessy K, Ronco P, Brown J: PPARgamma activation enhances cell surface ENaCalpha via up-regulation of SGK1 in human collecting duct cells. Faseb J 2003;17:1966-1968.

13 Yang T, Michele DE, Park J, Smart AM, Lin Z, Brosius FC $3^{\text {rd }}$, Schnermann JB, Briggs JP: Expression of peroxisomal proliferator-activated receptors and retinoid X receptors in the kidney. Am J Physiol 1999;277:F966973.

14 Zacchia M, Trepiccione F, Morelli F, Pani A, Capasso G: Nephrotic syndrome: new concepts in the pathophysiology of sodium retention. J Nephrol 2008;21:836-842.

15 Canessa CM, Schild L, Buell G, Thorens B, Gautschi I, Horisberger JD, Rossier BC: Amiloride-sensitive epithelial $\mathrm{Na}^{+}$channel is made of three homologous subunits. Nature 1994;367:463-467.

16 Bhalla V, Hallows KR: Mechanisms of ENaC regulation and clinical implications. J Am Soc Nephrol 2008;19:1845-1854.

17 Inoue T, Nonoguchi H, Tomita K: Physiological effects of vasopressin and atrial natriuretic peptide in the collecting duct. Cardiovasc Res 2001;51:470-480.

18 Son EJ, Kim SH, Park HY, Kim SJ, Yoon JH, Chung HP, Choi JY: Activation of epithelial sodium channel in human middle ear epithelial cells by dexamethasone. Eur J Pharmacol 2009;602:383-387.

19 Saad S, Agapiou DJ, Chen XM, Stevens V, Pollock CA: The role of Sgk-1 in the upregulation of transport proteins by PPAR-\{gamma\} agonists in human proximal tubule cells. Nephrol Dial Transplant 2009;24:11301141.

-20 Debonneville C, Flores SY, Kamynina E, Plant PJ, Tauxe C, Thomas MA, Munster C, Chraibi A, Pratt JH, Horisberger JD, Pearce D, Loffing J, Staub 0: Phosphorylation of Nedd4-2 by Sgk1 regulates epithelial $\mathrm{Na}^{+}$channel cell surface expression. Embo J 2001;20:7052-7059.

-21 Soundararajan R, Zhang TT, Wang J, Vandewalle A, Pearce D: A novel role for glucocorticoid-induced leucine zipper protein in epithelial sodium channel-mediated sodium transport. J Biol Chem 2005;280:3997039981.

22 Guan Y, Hao C, Cha DR, Rao R, Lu W, Kohan DE, Magnuson MA, Redha R, Zhang Y, Breyer MD: Thiazolidinediones expand body fluid volume through PPARgamma stimulation of ENaC-mediated renal salt absorption. Nat Med 2005;11:861-866. 


\section{Cellular Physiology $\quad$ Cell Physiol Biochem 2014;33:581-593 and Biochemistry \\ Chraïbi/Renauld: Rosiglitazone Enhances Sodium Transport in mpkCCD}

-23 Beltowski J, Rachanczyk J, Wlodarczyk M: Thiazolidinedione-induced fluid retention: recent insights into the molecular mechanisms. PPAR Res 2013;2013:628628.

-24 Artunc F, Sandulache D, Nasir O, Boini KM, Friedrich B, Beier N, Dicks E, Potzsch S, Klingel K, Amann K, Blazer-Yost BL, Scholz W, Risler T, Kuhl D, Lang F: Lack of the serum and glucocorticoid-inducible kinase SGK1 attenuates the volume retention after treatment with the PPARgamma agonist pioglitazone. Pflugers Arch 2008;456:425-436.

25 Tiwari S, Blasi ER, Heyen JR, McHarg AD, Ecelbarger CM: Time course of AQP-2 and ENaC regulation in the kidney in response to PPAR agonists associated with marked edema in rats. Pharmacol Res 2008;57:383392.

26 Renauld S, Tremblay K, Ait-Benichou S, Simoneau-Roy M, Garneau H, Staub O, Chraibi A: Stimulation of ENaC activity by rosiglitazone is PPARgamma-dependent and correlates with SGK1 expression increase. J Membr Biol 2010;236:259-270.

-27 Chen L, Yang B, McNulty JA, Clifton LG, Binz JG, Grimes AM, Strum JC, Harrington WW, Chen Z, Balon TW, Stimpson SA, Brown KK: GI262570, a peroxisome proliferator-activated receptor \{gamma\} agonist, changes electrolytes and water reabsorption from the distal nephron in rats. J Pharmacol Exp Ther 2005;312:718725 .

28 Vallon V, Hummler E, Rieg T, Pochynyuk O, Bugaj V, Schroth J, Dechenes G, Rossier B, Cunard R, Stockand J: Thiazolidinedione-induced fluid retention is independent of collecting duct alphaENaC activity. J Am Soc Nephrol 2009;20:721-729.

29 Nofziger C, Chen L, Shane MA, Smith CD, Brown KK, Blazer-Yost BL: PPARgamma agonists do not directly enhance basal or insulin-stimulated $\mathrm{Na}^{+}$transport via the epithelial $\mathrm{Na}^{+}$channel. Pflugers Arch 2005;451:445-453.

-30 Napoli JL: Quantification of physiological levels of retinoic acid. Methods Enzymol 1986;123:112-124.

31 Abramoff MD, Magelhaes PJ, Ram SJ: Image Processing with ImageJ. Biophotonics International 2004;11:36-42.

32 Caohuy H, Jozwik C, Pollard HB: Rescue of DeltaF508-CFTR by the SGK1/Nedd4-2 signaling pathway. J Biol Chem 2009;284:25241-25253.

-33 Pavlov TS, Levchenko V, Karpushev AV, Vandewalle A, Staruschenko A: Peroxisome proliferator-activated receptor gamma antagonists decrease $\mathrm{Na}^{+}$transport via the epithelial $\mathrm{Na}^{+}$channel. Mol Pharmacol 2009;76:1333-1340.

34 Blazer-Yost BL, Liu X, Helman SI: Hormonal regulation of ENaCs: insulin and aldosterone. Am J Physiol 1998;274:C1373-1379.

35 Erlij D, De Smet P, Van Driessche W: Effect of insulin on area and $\mathrm{Na}^{+}$channel density of apical membrane of cultured toad kidney cells. J Physiol 1994;481:533-542.

-36 Shimamoto K, Hirata A, Fukuoka M, Higashiura K, Miyazaki Y, Shiiki M, Masuda A, Nakagawa M, Iimura O: Insulin sensitivity and the effects of insulin on renal sodium handling and pressor systems in essential hypertensive patients. Hypertension 1994;23:I29-33.

-37 Garty H, Palmer LG: Epithelial sodium channels: function, structure, and regulation. Physiol Rev 1997;77:359-396.

-38 Marunaka Y, Hagiwara N, Tohda H: Insulin activates single amiloride-blockable Na channels in a distal nephron cell line (A6). Am J Physiol 1992;263:F392-400.

39 Ruan X, Zheng F, Guan Y: PPARs and the kidney in metabolic syndrome. Am J Physiol Renal Physiol 2008;294:F1032-1047.

40 Tontonoz P, Spiegelman BM: Fat and beyond: the diverse biology of PPARgamma. Annu Rev Biochem 2008;77:289-312.

41 Zhang H, Zhang A, Kohan DE, Nelson RD, Gonzalez FJ, Yang T: Collecting duct-specific deletion of peroxisome proliferator-activated receptor gamma blocks thiazolidinedione-induced fluid retention. Proc Natl Acad Sci US A2005;102:9406-9411.

42 Song J, Knepper MA, Hu X, Verbalis JG, Ecelbarger CA: Rosiglitazone activates renal sodium- and water-reabsorptive pathways and lowers blood pressure in normal rats. J Pharmacol Exp Ther 2004;308:426-433.

43 Yoshioka K, Wakino S, Homma K, Kanda T, Tatematsu S, Hasegawa K, Sugano N, Ito O, Omata K, Saruta T, Hayashi K: Renal cytochrome P450 as a determinant of impaired natriuresis by PPAR-gamma ligands in ovariectomized obese rats. Obesity (Silver Spring) 2008;16:965-971. 
44 Borsting E, Cheng VP, Glass CK, Vallon V, Cunard R: Peroxisome proliferator-activated receptor-gamma agonists repress epithelial sodium channel expression in the kidney. Am J Physiol Renal Physiol 2011;302:F540-551.

45 Monden T, Yamada M, Nihei Y, Kishi M, Tomaru T, Ishii S, Hashida T, Shibusawa N, Hashimoto K, Satoh T, Kasai K, Mori M: Unliganded RXR acts as an inhibitory factor on troglitazone-induced activation. Life Sci 2004;76:731-741.

46 Werman A, Hollenberg A, Solanes G, Bjorbaek C, Vidal-Puig AJ, Flier JS: Ligand-independent activation domain in the $\mathrm{N}$ terminus of peroxisome proliferator-activated receptor gamma (PPARgamma). Differential activity of PPARgamma1 and -2 isoforms and influence of insulin. J Biol Chem 1997;272:20230-20235.

47 Kim SP, Ha JM, Yun SJ, Kim EK, Chung SW, Hong KW, Kim CD, Bae SS: Transcriptional activation of peroxisome proliferator-activated receptor-gamma requires activation of both protein kinase A and Akt during adipocyte differentiation. Biochem Biophys Res Commun 2010;399:55-59.

48 Yin Y, Yuan H, Wang C, Pattabiraman N, Rao M, Pestell RG, Glazer RI: 3-phosphoinositide-dependent protein kinase- 1 activates the peroxisome proliferator-activated receptor-gamma and promotes adipocyte differentiation. Mol Endocrinol 2006;20:268-278.

49 Bens M, Chassin C, Vandewalle A: Regulation of $\mathrm{NaCl}$ transport in the renal collecting duct: lessons from cultured cells. Pflugers Arch 2006;453:133-146.

50 Lee IH, Campbell CR, Cook DI, Dinudom A: Regulation of epithelial $\mathrm{Na}^{+}$channels by aldosterone: role of Sgk1. Clin Exp Pharmacol Physiol 2008;35:235-241.

-51 Snyder PM, Olson DR, Thomas BC: Serum and glucocorticoid-regulated kinase modulates Nedd4-2-mediated inhibition of the epithelial $\mathrm{Na}^{+}$channel. J Biol Chem 2002;277:5-8. 